\title{
PRIVATE INTERNATIONAL LEGAL EDUCATION AND ITS RELEVANCE IN A EUROPEAN CONTEXT
}

\author{
Sergiu Popovici, PhD, Lecturer \\ West University of Timisoara, Faculty of Law \\ Bulevardul Eroilor de la Tisa 9A, Timișoara, Romania \\ sergiu.popovici@e-uvt.ro
}

\begin{abstract}
At the request of the European Parliament's Committee on Legal Affairs (JURI Committee), the European Parliament's Policy Department for Citizens' Rights and Constitutional Affairs issued a study titled "Building Competence in Commercial Law in the Member States", aimed at shedding light on cross-border commercial contracts and their operation in theory and practice, mainly within European Union Member States.

Most of the measures analysed and proposed for building competence in commercial law, despite the title of the study not being explicit in the matter, are cross-border measures, and thus of private international law. The last proposal of the study is the improvement of legal education in the field of private international law.

The present paper aims to assess the level of the Romanian legal system and its compatibility with the measures proposed in the above-mentioned study, while focusing, throughout, on the role of legal education. Is improving private international legal education the final (least important) measure to be taken? Can legal education in the member states be improved on a E.U. level, and if so, how? These are just some of the issues that the present paper looks to tackle.
\end{abstract}

Keywords: private international law, legal education, building competence, commercial law, Romanian legal system

\section{FOREWORD}

A research conducted upon the request of the European Parliament titled "Building Competence in Commercial Law in the Member States" was first published in September 2018. The debate was initiated by the Parliament starting from several empirical findings that Swiss and English law, as well as Swiss and English courts are chosen significantly more often than those of other Member States, and aims

1 Rühl, G., Building Competence in Commercial Law in the Member States (Legal and Parliamentary Affairs), Study for the JURI Committee, PE 604.980, September 2018 (hereinafter referred to as "The Study").

[http://www.europarl.europa.eu/RegData/etudes/STUD/2018/604980/IPOL_STU(2018)604980_ EN.pdf] Accessed 11.03.2019 
to increase commercial law competence in the EU by looking at cross-border commercial contracts and their operation in theory and practice.

Despite the title of the Study, its focus is not on commercial substantive law, as it might suggest, but mostly on cross-border matters, such as applicable law and international jurisdiction, choice of law and choice of forum, all of these of private international law (herein referred to as PIL). One of the many measures analysed and proposed by the Study is the improvement of legal education in the field. Before moving on to the analysis of what the study commissioned by the European Parliament reveals on building competence in commercial law, a succinct mention on terminology is in order. The present paper focuses on "Private International Legal Education", in the sense of legal education on private international law (herein referred to as "PIL education").

The point of the paper is to underline the fact that, despite its marginal situation and mention, the improvement of PIL education is probably the most important measure to be taken, as it is the only one upon which all others are inherently reliant, and without which they are unlikely to succeed.

After a general overview of the Study and of its proposed measures, I will attempt to underline the place and relevance of PIL education in relation to every one of its recommendations. From the perspective of the Romanian angle, the paper aims to provide an overview of the Romanian court system and legal education system in general, before an analysis of Romanian PIL education and its challenges, concluding with suggestions on how the Romanian system can improve, and how the European Union can contribute to an increase of the quality of PIL education .

\section{BUILDING COMPETENCE IN COMMERCIAL LAW IN THE MEMBER STATES - BRIEF OVERVIEW}

While the purpose of the paper is not to provide an analysis the proposed measures, an overview of all of them is essential in light of two of the main points that I intend to outline: firstly, that building competence in commercial law is almost synonymous, in the view of the Study, with building competence in Private International Law in commercial matters, and secondly, that all of the proposed measures are very much dependent, at least from the Romanian perspective, on the improvement of PIL education. 


\subsection{Context}

According to the Study's executive summary ${ }^{2}$, general heading, "Cross border commercial contracts are subject to a patchwork of legal rules and regulations. To overcome or at least mitigate the resulting uncertainty, commercial parties, internationally and within in the EU, frequently choose the applicable law and the competent court. When they do, English and Swiss law as well as English and Swiss courts turn out to be particularly popular: according to a number of empirical studies, the laws and the courts of both countries are more often chosen than the laws and the courts of other countries, notably other Member States. The European Parliament has, therefore, called for a debate about how commercial law competence in the EU can be increased. Commissioned by the Committee on Legal Affairs of the European Parliament, the following study seeks to contribute to this debate by taking a closer look at cross-border commercial contracts and their operation in theory and practice. It describes the applicable legal framework and analyses commercial practice as regards choice of law and choice of forum clauses. In addition, it discusses some of the implications that follow from the uneven distribution of commercial law competence across the EU. Finally, it makes a number of suggestions designed to make the settlement of international commercial disputes in the EU more attractive."

The Study is organized in four parts ${ }^{3}$ : the first part analyses the current legal landscape in which cross-border commercial contracts operate, shedding light on existing instruments relating to substantive commercial law as well as instruments that regulate choice of law and dispute resolution. The second part explores current commercial practices as regards choice of law and choice of forum clauses, analysing which laws and which courts are most frequently chosen by commercial parties including the reasons for parties' choices. The third part discusses some implications that follow from the current legal landscape and practice, including the implications of Brexit, while the fourth part submits a number of recommendations that will improve the framework for the settlement of international disputes both at the level of the Member States and at the level of the EU. This final part is the main focus of the present paper.

\subsection{Purpose of the Study}

According to some of the findings found under the heading with the same name $e^{4}$, the fact that uneven distribution across the EU of commercial law competence, as
Ibid., p. 7
Ibid, p. 11
Ibid, p. 7 
well as the popularity of certain laws and courts in relation to others, is not problematic by itself, but becomes an issue when not all parties can actually choose the law or the courts that are commonly perceived to be the best due to, for example, excessive costs.

The intended outcome of the Study is underlined under the "Outlook" heading of the executive summary ${ }^{5}$, and consists in fundamentally changing and improving the dispute resolution landscape in the EU, looking to ensure that "commercial parties have access to high-quality courts and procedures in all Member States irrespective of their size and their resources. As a consequence, they will be able to trust that they can enforce their claims across borders no matter where their contracting partner comes from and no matter whether they have agreed on a choice of forum. In addition, the EU as such will develop into an attractive place for the settlement of cross-border commercial disputes. It will be able to compete with some of the leading dispute settlement centres of the world which, in turn, should enhance the EU's attractiveness as a place for doing business".

To summarise, the objective of building competence in commercial law in fact consists of measures looking to improve the international side of commercial law, especially international jurisdiction and applicable law. When it comes to choice of law and of jurisdiction, the preferred fora and legislations for parties residing in Member States are the UK and Switzerland, leading to the conclusion that these states provide better performance in the field. By improving the level of competence in the other Member States, the parties will have a broader range for their choices without diminishing the quality of the legal act, and the possible impact of Brexit on the enforcement and recognition of UK judgements in the European Union will be mitigated. Thus, international dispute settlement in the Member States will become more attractive, and this seems to be the concrete purpose of the Study: to encourage parties to choose the court systems of EU Member States for the settlement of their litigations ${ }^{6}$.

\subsection{Measures proposed}

The measures analysed by the Study under Chapter 4, Recommendations ${ }^{7}$, are grouped under four categories: to the unification or harmonization of substantive commercial law; measures pertaining to the rule of choice of law; measures relat-

Ibid, p. 9

${ }^{6}$ It is interesting to note that, while the concrete measures proposed do aim at increasing competence in commercial law in its substance, the apparent goal underlined within the Study is to increase the perceived competence of the Member States' institutions in cross-border commercial matters Rühl, op. cit. note 1, p. 46 et seq. 
ing to the settlement of international disputes at the level of the Member States; and finally, improving the settlement of international disputes at the level of the EU, by establishing a European Commercial Court. I will attempt to provide a brief description of every recommendation in the Study, grouped under "hard" measures - measures with an impact on legislation, national or EU, versus "soft" measures - which affect processes and ideas which, despite looking to improve the legal process, do not have a direct effect on legislation.

\subsection{1. "Hard" measures}

Regarding the unification of substantive commercial law, while it remains a desideration, given the outcome of previous attempts in that direction, the author of the Study concedes that it should remain only as a long-term option.

Choice of law is treated in more detail, and three concrete recommendations are made concerning the Rome $\mathrm{I}^{8}$ and Rome II $^{9}$ Regulations:

- the adaptation of art. 3 of the Rome I Regulation to allow for the choice of a non-state law, such as the UNIDROIT Principles of International Commercial Contracts (UNIDROIT PICC) or the Principles of European Contract Law (PECL);

- the removal of any restriction in art. 3 of the parties' choice of law: while, according to the Study, the American approach of restricting choice of law is in no way recommendable, the parties should not even be restricted by mandatory provisions, in the sense that commercial parties should be allowed the choice of any law they want even if the contract is a purely domestic or a purely European one;

- the corresponding adaptation of art. 14 of the Rome II Regulation concerning choice of law in non-contractual matters, including the removal of the "freely negotiated" requirement, which is absent even from the current version of art. 3 of Rome I.

Probably the most impactful "hard" measures proposed are in the matter of dispute settlement in the European Union, both at the level of the Member States and at the level of the EU.

8 Regulation (EC) No 593/2008 of the European Parliament and the Council of 17 June 2008 on the law applicable to contractual obligations (Rome I), OJ EU 2008, L 177/6 (The Rome I Regulation)

9 Regulation (EC) No 864/2007 of the European Parliament and of the Council of 11 July 2007on the law applicable to non-contractual obligations (Rome II), OJ EU 2007, L 199/40 (The Rome II Regulation) 
At Member State level, two major reforms are recommended:

- introducing special procedures for cross-border commercial cases, looking to improve the speed and efficiency, fairness and predictability of judicial proceedings; the best approach envisaged is, however, not at Member State level, as the structure would suggest, but the establishment of an expedited procedure for cross-border commercial cases, identical across all the Member States, aimed to provide commercial parties with a fast and cost-saving option to settle their disputes;

- organising, at the level of every Member State, a specialised court or chamber for cross-border commercial cases, which would provide, in English, the application of the expedited procedure by competent professionals.

Another measure with a major impact is the establishment of a European Commercial Court, as a measure of improving dispute settlement at EU level, the details of which exceed the scope of the present paper. ${ }^{10}$

\subsection{2. "Soft" measures}

The Study recommends three "soft" measures, aimed at the general improvement of dispute settlement in the European Union, therefore as accessories to the three "hard" measures mentioned above. These are:

- improved training of judges and lawyers, especially in fields relevant for crossborder commercial cases, notably European private international law and international civil procedure, as well as proficiency in legal English;

- better access to European and foreign law, by establishing a centralised database with cases relating to European private international law and international civil procedure, as well as introducing a preliminary reference procedure between Member States;

- "finally", better legal education.

\subsection{The role of legal education within the Study}

Under the heading 4.3.3.3., as a sub sub-heading within the one generally dedicated to improving dispute settlement in the Member states, within "Further ac-

10 For a comprehensive analysis of the pros and especially cons of such a measure, see Rammeloo, S., Cross-border Commercial Litigation - Do We need a Permanent European Commercial Court? Analele UVT - Seria Drept, no. 1, 2019 (forthcoming) 
tions", the Study mentions ${ }^{11}$ : "Finally, the European legislature should also adopt measures relating to legal education in the field of cross-border commercial matters. As things stand at the moment, Member States approach the teaching of relevant subjects, notably private international law and international civil procedure but also comparative law in many different ways. While these subjects are mandatory in some Member States, they are not part of legal education at all in others. To ensure that judges across all Member States have a sufficient - minimum - understanding of the applicable rules and regulations, the European legislature should take actions to make sure that European private international law, European international civil procedure as well as comparative law play a much more prominent role in the education of future lawyers and judges. This may, for example, include the introduction of a provision that makes the basic core of these fields mandatory for all law students across the EU”.

This is the only mention of legal education within the Study, a "soft" measure at the outskirts, under a general heading subordinated to improving dispute settlement in the European Union. It almost seems as though the Study mentions legal education out of an abstract obligation to do so, without substantially acknowledging its importance.

However, most (if not all) of the "hard" measures proposed are reliant upon improved legal education in the field, specifically in PIL commercial maters.

Even the recommended changes in the phrasing of art. 3 Rome I and art. 14 Rome II, despite apparently not directly connected to the improvement of PIL education (a connection not considered by the Study, given its structure) would have the desired effect only in the context of professionals properly understanding the consequences and implications of these changes, a result which is achievable only by and after significant improvements in legal education.

The relevance of PIL education for the procedural "hard" measures is recognised within the Study itself, be it indirectly. Within the analysis of introducing special procedures for cross-border commercial cases, the Study acknowledges that "An insufficient number of judges and a lack of qualified judges may just as well be driving forces as a lack of resources, a lack of IT-infrastructure or inefficient rules of civil procedure. Against this background it remains an open question whether a European expedited procedure, as plausible as its introduction might appear, will actually tackle the real sources for lengthy proceedings. Chances are that inefficient and ineffective procedures are only one factor that impede speedy dispute settlement". "(...) the best procedure is of no use if the court and the judges

$11 \quad$ Rühl, op. cit. note 1, p. 7 and 9 
do not have the competence, expertise and experience to deal with cross-border commercial cases (...). In addition, the best procedure does not help if it is not frequently applied in practice". While not expressly stated, these aspects are undoubtedly relevant for the establishment of the European Commercial Court as well. ${ }^{12}$

Not least, improvement of legal education is the groundwork for the other proposed "soft" measures, despite being the last one mentioned. Adequate preparation of judges, lawyers and other practitioners in the matter is difficult to achieve through career trainings if there is no proper foundation on which to build, a foundation which may only be created during the higher education years. Moreover, building an adequate database of PIL cases and international civil procedure of the Member States requires significant background knowledge of the legal science involved on all levels, and for similar reasons as those stated above, would only be effective if judges, lawyers and other practitioners are sufficiently proficient in private international law to make proper use of the information therein.

To conclude, I argue that there is a large disparity between the marginal mention of legal education within the context of the Study and its actual importance, even for the other proposed measures.

\section{THE ROLE OF THE EUROPEAN UNION IN PRIVATE INTERNATIONAL LEGAL EDUCATION}

\subsection{The EU and higher education - general remarks}

According to art. 165 (1) TFEU (formerly art. 149 TEC, introduced as a principle for the first time by The Treaty on European Union, signed in Maastricht in 1992), "The Union shall contribute to the development of quality education by encouraging cooperation between Member States and, if necessary, by supporting and supplementing their action, while fully respecting the responsibility of the Member States for the content of teaching and the organisation of education systems and their cultural and linguistic diversity". It was after the Lisbon Council Meeting of $2000^{13}$ that education was referred to as a key policy field, which opened up the way for a degree of EU intervention in national education of unprecedented intensity ${ }^{14}$.

$12 \quad$ Ibid., p. 7

13 Lisbon European Council 23 and 24 March 2000 - Presidency Conclusions [http://www.europarl. europa.eu/summits/lis1_en.htm] Accessed 11.03.2019

14 Alexiadou, N., The Europeanisation of Education Policy: researching changing governance and 'new' modes of coordination, Research in Comparative and International Education, Vol. 2, No. 2, 2007, p. 102 
The principles of subsidiarity, limited powers and proportionality ${ }^{15}$, restricting the power of the EU's intervention in the policy of the Member States, remain particularly strong in the content or

organisation of their individual education systems ${ }^{16}$. As art. 165 (1) TFEU specifies, the EU can only encourage cooperation between Member States; direct reference to the cultural diversity and the concrete measures mentioned in art. 165 (2) TFEU $^{17}$ strengthens the clear restrictions found in paragraph 4 of the same normative text: "In order to contribute to the achievement of the objectives referred to in this Article:

- the European Parliament and the Council, acting in accordance with the ordinary legislative procedure, after consulting the Economic and Social Committee and the Committee of the Regions, shall adopt incentive measures, excluding any harmonisation of the laws and regulations of the Member States,- the Council, on a proposal from the Commission, shall adopt recommendations".

Despite this restriction in the matter of "hard" measures, the EU has been successfully active in promoting education in Europe in general, and higher education, in particular. In 1999, the Bologna Process began to advance the idea of a regional approach to higher education reforms and to meet the demands of the "knowledge economy", following the 1997 report of the European Commission "Towards a Europe of Knowledge". ${ }^{18}$ The Bologna Process is an intergovernmental cooperation of 48 European countries in the field of higher education. It guides the collective effort of public authorities, universities, teachers, and students, together with stakeholder associations, employers, quality assurance agencies, international

15 Bercea, R., Drept comunitar. Principii, C.H. Beck, Bucharest, 2007, pp. 327-348

16 Alexiadou, op. cit. note 14, p. 103

17 "- developing the European dimension in education, particularly through the teaching and dissemination of the languages of the Member States, - encouraging mobility of students and teachers, by encouraging inter alia, the academic recognition of diplomas and periods of study, - promoting cooperation between educational establishments, - developing exchanges of information and experience on issues common to the education systems of the Member States, - encouraging the development of youth exchanges and of exchanges of socio-educational instructors, and encouraging the participation of young people in democratic life in Europe, - encouraging the development of distance education, - developing the European dimension in sport, by promoting fairness and openness in sporting competitions and cooperation between bodies responsible for sports, and by protecting the physical and moral integrity of sportsmen and sportswomen, especially the youngest sportsmen and sportswomen."

18 Barett, B., Globalization and Change in Higher Education: The Political Economy of Policy Reform in Europe, Palgrave Macmillan (Springer), Cham, Switzerland, 2017, p. 2 
organisations, and institutions, including the European Commission, on how to improve the internationalisation of higher education ${ }^{19}$.

As a result of the Bologna process, The European Higher Education Area (EHEA) was established, a unique international collaboration on higher education implementing a common set of commitments: structural reforms and shared tools. The aim is for countries, institutions and stakeholders of the European area to continuously adapt their higher education systems making them more compatible and strengthening their quality assurance mechanisms, thus increasing staff and students' mobility and facilitating employability ${ }^{20}$, by establishing, among others, the European Credit Transfer and Accumulation System (ECTS) and the mutual recognition of diplomas.

The Erasmus and Erasmus $+{ }^{21}$ programmes started as a precursor to the Bologna process, its success later increased by the other EU initiatives in higher education. Other more recent initiatives such as the EU Youth Strategy ${ }^{22}$ are the result of the directions outlined in the Communication from the Commission to the European Parliament, the Council, the European Economic and Social Committee and the Committee of the Regions on a renewed EU agenda for higher education ${ }^{23}$.

\subsection{What measures could the EU take to improve private international legal education?}

To begin an analysis of the measures that the EU may undertake in order to improve PIL education, I will begin with the only concrete recommendation found within the Study: "(...) take actions to make sure that European private international law, European international civil procedure as well as comparative law play a much more prominent role in the education of future lawyers and judges. This may, for example, include the introduction of a provision that makes the basic core of these fields mandatory for all law students across the EU”.

19 [https://ec.europa.eu/education/policies/higher-education/bologna-process-and-european-higher-education-area_en] Accessed 11.03.2019

20 [http://www.ehea.info/] Accessed 11.03.2019

${ }_{21}$ [https://ec.europa.eu/programmes/erasmus-plus/about_en] Accessed 11.03.2019

22 The EU Youth Strategy is the framework for EU youth policy cooperation for 2019-2027, based on the Council Resolution of 26 November 2018. EU youth cooperation shall make the most of youth policy's potential. It fosters youth participation in democratic life; it also supports social and civic engagement and aims to ensure that all young people have the necessary resources to take part in society. [https://ec.europa.eu/youth/policy/youth-strategy_en] Accessed 11.03.2019

23 [https://eur-lex.europa.eu/legal-content/EN/TXT/?qid=1496304694958\&uri=COM:2017:247:FIN] Accessed 11.03.2019 
In essence, the only proposal in the Study is to make the basic core of PIL commercial law and procedural law a compulsory discipline for all law students studying in the EHEA. It is unclear what the author of the Study understands by "provision"; despite the term implying a possible legislative initiative, it must be analysed in the context of the express exclusion of harmonisation measures for Member States, and therefore may only relate to the so-called "soft" measures.

The question remains: can and should the EU do more than it is doing in general in order to promote PIL higher education? Despite the fact that the Study offers little concerning the means by which the EU should go about increasing the quality of PIL education, its merit consists of the fact that, be it marginally, it does raise the issue of improving the quality of legal education in cross-border commercial matters.

It is therefore my opinion that the EU can contribute to the improvement of PIL education in Member States, by focusing on the cross-border elements in its recommendations and other secondary legislation. Having the basics of PIL as a compulsory discipline in undergraduate studies could be a start, however not sufficient, as I will attempt to argue below. Increased focus on the cross-border elements should accompany all of the later trainings of legal professionals, and the allocation of funding for research and innovation in law should increasingly target the cross-border elements, if the purpose within the Study is to be achieved ${ }^{24}$.

\section{THE ROMANIAN EXPERIENCE}

\subsection{Short description of the Romanian court system}

The Romanian ordinary court private law system ${ }^{25}$ is a 3 tier pyramidal system, above which is the High Court of Cassation and Justice. ${ }^{26}$ The lower tier is made out of 176 district courts (Romanian judecătorie), the middle tier by 42 tribunals, corresponding to the 41 administrative divisions (Romanian județe) plus Bucharest, and the upper tier by 15 courts of appeal. Depending on criteria varying from value of the litigation to subject matter, the first two tiers may be courts of first instance. The rule is that judgements given by courts of first instance may be

\footnotetext{
24 There certainly are many and more options for the EU to improve the quality of PIL higher legal education, but analysing many of these in detail would exceed the scope of this presentation, which relies mostly on the peculiarities of the Romanian system. For an approach originating from the Polish system, see Czarnota, A.; Paździora, M.; Stambulski, M., The Hidden Curriculum in Legal Education, Krytyka Prawa, tom. 10, no. 2, 2018, pp. 114-129

25 [https://e-justice.europa.eu/content_ordinary_courts-18-ro-en.do?init=true\&member=1] Accessed 12.03.2019

26 [http://www.scj.ro/en] Accessed 12.03.2019
} 
appealed with the immediately upper court. The special appeal, or review as the e-justice website uses as a translation for the Romanian recurs was, after the changes to the Romanian Civil Procedure Code enacted in 2013, transformed into a proper extraordinary appeal, by the establishment of a threshold under which decisions given in appeal were not reviewable. However, the Constitutional Court ${ }^{27}$ changed its initial jurisprudence and recently declared any threshold, regardless of its quantum, to be unconstitutional, which practically transforms the review back into an ordinary remedy, leading to a de facto conflict between two of the highest courts in the Romanian judiciary ${ }^{28}$.

Specialisation within the Romanian judiciary remains basic. The tendency in Romanian private law after the coming into force of the New Civil Code and the repealing of the former Commercial Code is to unify private law ${ }^{29}$, a current susceptible to hinder further specialisation. Despite the fact that the former legislation specifically mentioned the jurisdiction of separate commercial courts, only three were actually established, and are now functioning as specialised tribunals $s^{30}$, in principle dealing with litigations between professionals. There is only one specialised court in family matters, all other specialisations operating within the courts themselves, by divisions into chambers (Romanian secții). The High Court of Cassation and Justice has a basic division in four chambers for ordinary litigations: Civil, $2^{\text {nd }}$ Civil (litigations between professionals), Criminal, and Administrative (including fiscal), while it is up to every court to decide its own division into separate chambers, in principle according to their logistical needs. This leads to large disparities, from no specialisation at all in some of the smaller district courts (in which the same judge deals with every case, from criminal to labour to family, administrative and commercial litigations) to having several chambers for the same legal matter, the highest specialisation being found with the Bucharest courts ${ }^{31}$.

\subsection{Brief overview of the Romanian legal education system}

For the academic year of 2016-2017, a total number of 42 accredited law faculties were functioning in Romania, 18 of which were State or public law schools, while the remaining 24 were attached to private universities ${ }^{32}$. According to Law No.

\footnotetext{
27 [https://www.ccr.ro/en] Accessed 12.03.2019

28 Chis, A., Curtea Constituțională vs. Inalta Curte de Casație și Justiție, Analele UVT - Seria Drept, no. 2, 2018, pp. 210-220

29 Nicolae, M., Unificarea dreptului obligatiilor civile si comerciale, Hamangiu, Bucharest, 2015

30 [https://e-justice.europa.eu/content_specialised_courts-19-ro-en.do?member=1] Accessed 12.03.2019

31 [http://www.cab1864.eu/?pag=97] Accessed 12.03.2019

32 Bojin, L., The Stakeholders in the Romanian Legal Education and their Influence over the Curricula and Teaching Methods, Ońati Socio-legal Series, vol. 7, no. 8, 2017 - Legal Education in Europe. Chal-
} 
1/2011 on National Education ${ }^{33}$, in public law schools, only part of the student places are subsidized by the State, the remaining ones functioning in the same way they do in a private university, by paying a yearly tuition fee.

After the transition years in the 90 's ${ }^{34}$, legal education was, as the entire higher education system, the object of reforms in the 2000's as a result of the commitment to implement the Bologna process. Consequently, all accredited law schools adopted the $4+1$ or $4+2$ system (i.e. four years of undergraduate studies and one or two years of postgraduate studies, followed by three years for $\mathrm{PhD}$ studies) and the system of transferable credits ${ }^{35}$. During the same process, the curricula of the law schools was unified, with a number of disciplines that are mandatory in all law schools (the so-called "common trunk", which includes civil law, commercial law, labour law, criminal law, constitutional law, administrative law, civil and criminal procedure, public and private international law, EU institutional law, general legal theory), while the others can be chosen by each of the law schools, in the name of universities' autonomy ${ }^{36}$.

The undergraduate legal education period is four years. Upon graduation from law school, students are allowed to access the legal professions. The criteria differ, but neither of these professions requires post-graduate studies to be accomplished. The mainstream legal professions are ${ }^{37}$ : lawyer, judge or prosecutor (whose organisation is unified under the umbrella-category of magistrates), notary, registrar in court, in-house legal counsellor (need not to be member of the bar), civil servant. Besides these, there is a specific professional category called legal advisers, organ-

lenges and Prospects, p. 1613. The list of accredited private higher education institutions and their domains is updated yearly by Government Decision (Romanian Hotărâre). The present data, resulting from Decision no. 695/2018, does not present any significant variations. For an updated list of all accredited universities in Romania, see the official website of the Ministry of Education: [https://www. edu.ro/institutii\%20de\%20inv_superior\%20particulare\%20acreditate] Accessed 12.03.2019

33 Published in the Official Monitor of Romania No. 18 of 10 January 2011, last updated on 16 March 2018

34 In the first decade after the fall of communism, the higher education system underwent a number of important transformations: the number of universities (both public and private) increased significantly, new programmes emerged, disciplines that used to be marginalized in the older regime, such as law or economics were now reinvigorated and the number of students raised exponentially: Curaj, A.; Deca, L.; Polak, E.E; Salmi, J., Higher Education Reforms in Romania. Between the Bologna Process and National Challenges, Springer, Cham, 2015, pp. 2-3; for another approach on the transition period, see Birzea, C., Back to Europe and the Second transition in Central Eastern Europe, Orbis Scholae, Vol. 2, No. 2, 2008, pp. 105-113

35 Bojin, op. cit. note 32, p. 1614

36 Baias, F.A.; Danisor, D.C.; Vasilescu, P., Standardele de conţinut şi programul cadru pentru domeniul „Drept”, Analele Universitatii Titu Maiorescu - Seria Drept, no. 4, 2007, p. 146

37 Bojin, op. cit. note 32, p. 1616 
ised in a professional order, just like the lawyers, the main difference being that only the latter can represent natural persons in court. From a functional point of view, it is quite difficult to distinguish them from lawyers ${ }^{38}$.

Historically, the Romanian legal system and, implicitly, Romanian legal academia lies on at least two layers, the foundational French legal tradition and the more recent communist heritage, with both playing a major role in today's law schools' configuration and their vision of academic freedom ${ }^{39}$. In terms of pedagogy, the Romanian legal education system has inherited from the French tradition the "cours magistral" (Romanian curs) where a professor presents, uninterrupted by the students, "the truth" about a specific legal institution and the "travaux dirigés" (Romanian seminarii), where a teaching assistant, usually a disciple, a PhD student who has not already been given the right to entry in the community by its gatekeepers, reiterates, in a more or less interactive way, the words of the profes$\operatorname{sor}^{40}$.

Admission to the professions of magistrate, notary and lawyer is subject to difficult exams ${ }^{41}$, while for the other professions no further exam is required after graduation. If the students want to follow a career as magistrates (judges or prosecutors), they have to be admitted to the National Institute of Magistracy (Romanian Institutul Superior al Magistraturii - INM), while if they want to become lawyers, they have to pass the Bar admission exam. Those entering the INM follow further training for 2 years, after which they may practice as judges or prosecutors, starting with a three-year period as trainees (Romainan stagiari). The lawyers must undergo two years of apprenticeship under the supervision of a lawyer and of the National Institute for the Professional Training of Lawyers (Romanian Institutul National pentru Pregatirea si Perfectionarea Avocatilor - INPPA) and afterwards they have to pass another exam after which they can freely practice the profession of lawyer, either in an independent office or as de facto employees of one of the larger law firms. ${ }^{42}$

Starting with the second half of the years 2000, the population enrolled in higher education has been constantly decreasing: demographics indicate a strong decline in birth rates while many young people leave the country in search for a better education or better paid jobs within the European Union. Romania continues to

\footnotetext{
$38 \quad$ Ibid.

39 Mercescu, A., Law Schools between Autonomy and Democracy. The Case of Romanian Legal Academia, The $9^{\text {th }}$ CEE Forum (forthcoming)

40 Ibid.

41 Ibid.

42 Ibid.
} 
have one of the smallest number of graduates in the European Union, according to Eurostat 2015, while the market is still oversaturated with professionals holding a diploma from the "golden age" of the academic "industry". ${ }^{43}$

\subsection{Private International Law in the Romanian legal landscape}

The Romanian legal system is relatively self-sufficient, and from that a self-sustainability of legal education and research arises. Consequently, the legal education system is also focused on deepening the knowledge of national law, which also negatively impacts international legal research ${ }^{44}$. Accession to legal practice (magistrates, lawyers, notaries, executors, legal advisors) is predominantly dependent on in-depth knowledge of national legislation, only some general basic knowledge in EU law and the European Convention of Human Rights (ECHR) being required. Further training of lawyers and magistrates have no specific focus on private international law, the curricula for both the INPPA ${ }^{45}$ and the INM ${ }^{46}$ having a very small international dimension, consisting of basic focus on EU institutional law and the ECHR.

As seen above, PIL is a compulsory discipline in all of the relevant Romanian law schools' curricula. Since it is a subject that requires a lot of interdisciplinary ${ }^{47}$ knowledge $e^{48}$, it is usually programmed in the final semester $\left(8^{\text {th }}\right.$ out of 8$)$ of the undergraduate studies. While this placement is justified by the required background knowledge, it has the disadvantage of being situated in close proximity to

$43 \quad$ Ibid.

44 An underdeveloped international dimension is common to most of the largest legal education institutions in Romania, and reflects in relatively poor h-indexes and very few Romanian contributions to publications indexed in the Web of Science, Scopus or ERIH in the legal field

45 Curricula for the INPPA: [ http://www.inppacentral.ro/programele-de-studiu/] Accessed 14.03.2019. The only mention of PIL is as one of 21 directions of continual professional preparation of lawyers

46 Curricula for the INM: [http://www.inm-lex.ro/displaypage.php?p=45\&d=2457] Accessed 14.03.2019. No mention of PIL

47 For thorough approaches on interdisciplinarity as an element of legal education, see Mercescu, A., Interdisciplinarity as Resilience in Legal Education, The Second World Congress on Resilience: From Person to Society, Medimond International Proceedings, Bologna, 2014, pp. 879-884; Bercea, R., Legal Culturalism as Resilience, The Second World Congress on Resilience: From Person to Society, Medimond International Proceedings, Bologna, 2014, pp. 847-852

48 For one to understand the cross-border peculiarities of civil and commercial law, family law, successions, etc., one must master the basics of all these disciplines of substantive law. This reality also affects research: there is an extremely small number of Romanian researchers whose main object of focus is private international law: most are specialists in their main field (e.g. family, law, successions, civil procedure), who later deviated towards some of the cross-border elements of their discipline. I myself started my research career in commercial law, and later (unlike most other researchers), became predominantly focused on PIL 
the admission exams in the legal professions, none of which require knowledge in international law in general, let alone in PIL.

After Romania's accession to the EU, in 2007, the reform of the judicial system accelerated and the fight against corruption intensified, which put legal professionals under the spotlight ${ }^{49}$. As a consequence, the professions felt a lot of pressure to improve on their admission standards. This has triggered a professionalising effect on law schools whose main objective now resides in having as many successful graduates as possible in the national exams $s^{50}$, therefore leading to a marginalisation of private international law.

These shortcomings: the general self-sustainability of the Romanian legal education system, resulting in a marginal (almost formal) approach on (private) international law, and the specific disadvantage of placing PIL in the final semester of undergraduate studies, when the students' main focus is on preparing for the license examination (where there is absolutely no requirement of PIL knowledge) and on the later profession admission exams (which also do not require even the most basic commandment of private international law), are merely the tip of the iceberg. Going deeper, we find that legal higher education in Romania is, as a rule, only exceptionally based on problem solving, and relies almost entirely on memorisation, which is a further hindrance for PIL, a discipline with very concrete purposes, where deductive reasoning is of paramount importance. This issue originates, however, at the bottom of the iceberg: despite several reforms, education in

49 As described in Maci, M., Anatomia unei imposturi. O școală incapabilă să învețe. Trei, Bucharest, 2016, p. 58, p.137, paraphrased by Mercescu, in op.cit., note 39, rural young people felt encouraged to move to the city where they could pursue academic studies. Equally encouraged to enroll in higher education were those already living in the city who would have wanted to graduate from university but could not enter higher education prior to 1989 because the system was very rigid, based on a limited number of places imposed by the centre. Thus, there was a strong demand for the increase of the number of students both from the bottom but also from above, since the state needed qualified personnel able to work in the new emergent administration. However, the older universities, constantly under-subsidized - even today Romania's higher education sector occupies only about $3 \%$ of GDP - did not have the capacity to sustain such a growth and soon private institutions appeared that granted diplomas without much consideration for quality. As a result, the established universities felt threatened by what seemed to be a flourishing industry and implemented a system that made available a number of supplementary places based on fees. The quality of education declined steadily. Since faculties wanted students who pay taxes, everyone was allowed to both enter and exit the system in a period of time as short as possible. This led to an inflation of graduates poorly equipped for an equally poorly developed job market. The kind of training received did not involve a serious reflection on the systemic transformation of the Romanian society. The emergency of producing new students, new programmes adapted to the market economy, new professors and new elites precluded a thorough examination of the country's possibilities and future directions and encouraged superficiality, mimetic and uncritical thinking

50 Mercescu, op.cit. note 39. 
Romania in general is only exceptionally base on problem-solving: in Romanian, studying is almost synonymous to memorising. Going even deeper, one needs to address the issue of motivation: the Romanian educational system has no method to discover, let alone to cultivate the pupils' specific skills, leading to very few cases where students choose their higher education based on what they enjoy doing or on what they are naturally inclined to. This is particularly true for legal educa$\operatorname{tion}^{51}$, where there is very little variation in the optional curricula, and the profession admission exams are the same, as candidates will need to prove proficiency in both private and criminal law (with some focus on family law and successions for notaries) regardless of what they intend to later focus their profession on.

It is my view that this complex of circumstances has led to an overall relatively poor performance of Romanian PIL education, and consequently on private international law on all levels: practice, jurisprudence and research.

It is because of inadequate PIL basic training that parties and lawyers are not well acquainted with PIL on an elementary level ${ }^{52}$, meaning that the issues of international jurisdiction and applicable law are rarely raised in front of Romanian courts; if Romanian courts do claim international jurisdiction, they will apply foreign law only exceptionally. This leads to comparatively few cases of PIL jurisprudence, and these not of the best quality.

\subsection{Possible improvement measures}

In section 2.3 above I argued that improvement of PIL education lies at the foreground of all of the proposed measures in the European Parliament Study. I also hold that insufficient focus in Romanian legal education on private international

51 My conclusion is drawn not based on empirical studies, but rather on constant interactions with students in formal and informal environments. I do not recall interacting final year law students who genuinely enjoyed "studying" law, or who were eagerly awaiting to start their practice out of love for the profession. The main motivations encountered are either financial (legal professions are still perceived to be very lucrative) or based on social status (lawyers and magistrates are very highly regarded in society in general). Not necessarily unexpected in a society still based on the nuclear family, even in urban centres, family pressure came up over and over again as the main motivator for trying to graduate from law school. I have encountered many former students who, after fulfilling this "duty" to their family and got their degree, followed professions with absolutely no connection with their higher education

52 Some of the shortcomings encountered during my legal practice and research: exequatur requested and granted in the matter of maintenance obligations; a reputed practitioner looking for the answer on jurisdiction in the Rome III Regulation; pervasive lack of awareness of The Hague Choice of Court Convention of 2005; etc. For normative inadequacies in the matter of insolvency, see Popovici, S., Cross-Border Insolvency in the New Insolvency Code of Romania, The Second World Congress on Resilience: From Person to Society, Medimond International Proceedings, Bologna, 2014, pp. 907-910 
law is the main reason for relatively poor performances of Romanian practitioners and researchers in cross-border matters in general.

I do not believe any of the "hard" measures recommended in the Study would genuinely help improve competence in cross-border commercial law in Romania, not because of their inherent shortcomings ${ }^{53}$, but mainly because their application would require a level of expertise in private international law which I believe at the moment Romania is lacking. Specialisation within the court system is relatively low as it is, so establishing courts or chambers dealing only with cross-border cases is simply not feasible in the current judicial context. A specific uniform procedure for commercial cases with a foreign element may help, however not significantly, in my opinion, given the relative low success in Romania of existent uniform procedures, such as the European Order of Payment ${ }^{54}$. While the establishment of a permanent European Commercial Court is certainly a very intriguing prospect, I believe it would do little to improve the quality of the Romanian judiciary in cross-border commercial matters.

Having PIL as a compulsory discipline is simply not enough if there is no additional support. While discussing substantial reforms of the Romanian education system itself surpasses the scope of this paper, there are some measures that I believe could help a short-term increase of Romanian competence in cross-border commercial matters. The most obvious of these would be to include the basics of PIL as a requirement for accession to the legal professions, a first element which would compel the law schools to focus more on cross-border aspects. Further on, initial preparation of magistrates and lawyers should also focus on PIL. These initial measures have the potential to generate increased jurisprudence of better quality in cross-border (not only) commercial cases, and therefore to an increase in the quality of PIL research, all of which would then contribute to the improvement of PIL education.

To conclude, if not in other Member States, in order to build competence in private international commercial law, the focus for Romania should be predominantly on improving PIL education. Since the Romanian legal system is relatively self-sufficient, as stated above, it is unlikely that a national endeavour will emerge in that direction, so any initiative from the EU underlining the need to improve PIL education would help raise awareness of this necessity. EU intervention in the curricula of law schools or in the content of the admission exams into the legal professions, closer to a "hard" measure than a "soft" one, is probably not

\footnotetext{
53 Rammeloo, op. cit., note 10

54 When taking into account the legal English element, the issue becomes even more problematic
} 
to be expected in the near future. However, the European higher education programmes have proven to be a success, and their focus (if not the establishment of a separate direction with its main preoccupation on cross-border aspects) could lead to national measures susceptible of improving Romanian performance in private international commercial law.

These measures, however, only come to serve as a short-term solution to what I mentioned above as being the "tip of the iceberg". Making private international law (at least its basics) compulsory for admission to the legal professions would compel law schools to focus more on the legal relationships with a foreign element, and would also significantly build on the students' motivation to study PIL. Introducing cross-border elements as compulsory in the initial training of magistrates and lawyers would also lead to the increase of the practitioners' PIL knowledge. Working to remove this "tip" would, however, only serve to bring PIL closer to the level of proficiency in national law, which would definitely be a good short-term solution.

European funding for improvement of PIL would work to the same end. As it is now, it is focused on cross-border collaborations between institutions, where the deficit in Romania makes it very difficult to access research and development funding on private international law. Even if focused on domestic improvement alone, EU intervention would at best help improve PIL knowledge to a level comparable with that of national law. Substantial improvement, however, is only possible long-term, and only with a gradual reform of the entire educational system from the focus on memorisation to that on problem solving and aptitude learning, which is, however, far outside the scope of this paper.

\section{CONCLUSIONS}

Building competence in commercial law in the member states, in the view of the European Parliament, is almost synonymous with building competence in private international law in commercial matters. In the Study commissioned in order to reach this goal, a varied set of "hard" and "soft" measures have been recommended. While these are, in principle, hard to argue with, practically and logistically they would be difficult to enact.

Improvement of legal education is mentioned as a marginal "soft" measure as a subdivision of the recommendations given to improve the attractiveness of dispute settlement in the EU; it is my view, however, that this should be the prime measure, since without it, all of the others (hard and soft) would lack an adequate foundation and therefore would probably not have the desired effect. 
Making PIL compulsory in law schools, the only recommendation in the Study for improvement of legal education, while potentially useful, has proven its limits in the Romanian legal landscape. In the short term, concrete measures such as introducing PIL as a compulsory discipline in the admission exams to the legal professions, while also improving the curricula of the institutions empowered with the initial and continuous training of lawyers, magistrates and the other professions in order to include elements of private international law, could contribute to the desired effect: building competence in cross-border commercial law in Romania. Given the relative self-sustainability of the Romanian legal system, initiatives from the EU, even in the form of "soft" measures, could prove especially valuable.

In the long term, however, genuine improvement of competence in cross-border commercial law requires an overhaul of the education system in general, with less focus on memorisation and increased focus on problem-solving and aptitude learning. It is not inconceivable, in my view, for the EU to assess national educational systems and to encourage departure from the very rigid systems of (almost purely) theoretical learning, such as the Romanian one; an analysis of the measures that the EU could take, however, would far exceed the scope of this paper.

\section{REFERENCES}

\section{BOOKS AND ARTICLES}

1. Alexiadou, N., The Europeanisation of Education Policy: researching changing governance and 'new' modes of coordination, Research in Comparative and International Education, Vol. 2, No. 2, 2007, p. 102-116

2. Baias, F.A.; Danisor, D.C.; Vasilescu, P., Standardele de conţinut şi programul cadru pentru domeniul „Drept”, Analele Universitatii Titu Maiorescu - Seria Drept, no. 4, 2007, pp. 138161

3. Barett, B., Globalization and Change in Higher Education: The Political Economy of Policy Reform in Europe, Palgrave Macmillan (Springer), Cham, Switzerland, 2017

4. Birzea, C., Back to Europe and the Second transition in Central Eastern Europe, Orbis Scholae, Vol. 2, No. 2, 2008, pp. 105-113

5. Bercea, R., Drept comunitar. Principii, C.H. Beck, Bucharest, 2007

6. Bercea, R., Legal Culturalism as Resilience, The Second World Congress on Resilience: From Person to Society, Medimond International Proceedings, Bologna, 2014, pp. 847-852

7. Bojin, L., The Stakeholders in the Romanian Legal Education and their Influence over the Curricula and Teaching Methods, Ońati Socio-legal Series, vol. 7, no. 8, 2017 - Legal Education in Europe. Challenges and Prospects, p. 1610-1635

8. Chis, A., Curtea Constituționala vs. Inalta Curte de Casatie si Justitie, Analele UVT - Seria Drept, no. 2, 2018, pp. 210-220 
9. Curaj, A.; Deca, L.; Polak, E.E; Salmi, J., Higher Education Reforms in Romania. Between the Bologna Process and National Challenges, Springer, Cham, 2015

10. Czarnota, A.; Paździora, M.; Stambulski, M., The Hidden Curriculum in Legal Education, Krytyka Prawa, tom. 10, no. 2, 2018, pp. 114-129

11. Maci, M., Anatomia unei imposturi. O școală incapabilă să învețe, Trei, Bucharest, 2016

12. Mercescu, A., Interdisciplinarity as Resilience in Legal Education, The Second World Congress on Resilience: From Person to Society, Medimond International Proceedings, Bologna, 2014, pp. 879-884

13. Mercescu, A., Law Schools between Autonomy and Democracy. The Case of Romanian Legal Academia, The 9th CEE Forum (forthcoming)

14. Nicolae, M., Unificarea dreptului obligatiilor civile si comerciale, Hamangiu, Bucharest, 2015

15. Popovici, S., Cross-Border Insolvency in the New Insolvency Code of Romania, The Second World Congress on Resilience: From Person to Society, Medimond International Proceedings, Bologna, 2014, pp. 907-910

16. Rammeloo, S., Cross-border Commercial Litigation - Do We need a Permanent European Commercial Court? Analele UVT - Seria Drept, no. 1, 2019 (forthcoming)

\section{EU LAW}

1. Treaty on the Functioning of the European Union, OJ C326/47

2. Regulation (EC) No 593/2008 of the European Parliament and the Council of 17 June 2008 on the law applicable to contractual obligations (Rome I), OJ EU 2008, L 177/6 (The Rome I Regulation)

3. Regulation (EC) No 864/2007 of the European Parliament and of the Council of 11 July 2007on the law applicable to non-contractual obligations (Rome II), OJ EU 2007, L 199/40 (The Rome II Regulation)

\section{LIST OF NATIONAL REGULATIONS, ACTS AND COURT DECISIONS}

1. Romanian Civil Procedure Code (Law 134/2010), republished in the Official Monitor of Romania No. 247 of 10 April 2015

2. Romanian Civil Code (Law 287/2009), republished in the Official Monitor of Romania No. 505 of 15 July 2011

3. Law No. 1/2011 on National Education, Official Monitor of Romania No. 18 of 10 January 2011

4. Hotarare de Guvern No. 695/2018, Official Monitor of Romania No. 786 of 13 September 2018

\section{WEBSITE REFERENCES}

1. Rühl, G., Building Competence in Commercial Law in the Member States (Legal and Parliamentary Affairs), Study for the JURI Committee, PE 604.980, September 2018 
2. [http://www.europarl.europa.eu/RegData/etudes/STUD/2018/604980/IPOL_ STU(2018)604980_EN.pdf] Accessed 11.03.2019

3. Lisbon European Council 23 and 24 March 2000 - Presidency Conclusions [http://www. europarl.europa.eu/summits/lis1_en.htm] Accessed 11.03.2019

4. The Bologna Process [https://ec.europa.eu/education/policies/higher-education/bolognaprocess-and-european-higher-education-area_en] Accessed 11.03.2019

5. The European Higher Education Area [http://www.ehea.info/] Accessed 11.03.2019

6. The Erasmus+ Programme [https://ec.europa.eu/programmes/erasmus-plus/about_en] Accessed 11.03.2019

7. The EU Youth Strategy [https://ec.europa.eu/youth/policy/youth-strategy_en] Accessed 11.03.2019

8. Communication from the Commission to the European Parliament, the Council, the European Economic and Social Committee and the Committee of the Regions on a renewed EU agenda for higher education

9. [https://eur-lex.europa.eu/legal-content/EN/TXT/?qid=1496304694958\&uri=COM:201 7:247:FIN] Accessed 11.03.2019

10. Romanian ordinary court system [https://e-justice.europa.eu/content_ordinary_courts-18ro-en.do?init=true\&member=1] Accessed 12.03.2019

11. Romanian High Court of Cassation and Justice [http://www.scj.ro/en] Accessed 12.03.2019

12. Romanian Constitutional Court [https://www.ccr.ro/en] Accessed 12.03.2019

13. Romanian specialised court system

14. [https://e-justice.europa.eu/content_specialised_courts-19-ro-en.do?member=1] Accessed 12.03.2019

15. The Bucharest Court of Appeal [http://www.cab1864.eu/?pag=97] Accessed 11.03.2019

16. Accredited universities in Romania

17. [https://www.edu.ro/institutii\%20de\%20inv_superior\%20particulare\%20acreditate] Accessed 11.03.2019 